\title{
Simple Discussion on How to Improve Teaching and Educating Effect Teachers in Higher Vocational College
}

\author{
Li Guofeng \\ Shandong Transport Vocational College \\ Weifang, Shandong
}

\begin{abstract}
Imparting knowledge and educating people is teachers' sacred mission, through the process of teaching to realize the function of educating people. Teachers must have good moral quality, professional quality, strong dedication and sense of responsibility, care for and love students. Teacher should also instruct and influence others by their words and deed, make themselves examples and train students to have noble sentiments and good qualities.
\end{abstract}

Key words- teacher; student; teaching; imparting knowledge and educating people

\section{INTRODUCTION}

Han $\mathrm{Yu}$, the famous writer, in "Teachers Say" wrote, "A teacher passes knowledge, teaches various subjects and solve problems ". That is to say, the role of teachers is to pass truth, explain knowledge and solve problems. How to understand imparting knowledge and educating people? First, imparting knowledge and educating people means teachers are concerned about students. During the process of imparting professional knowledge and occupational skills, teachers educate students by their own moral behavior and personality charm and guide them to realize their right value pursuit and enable students to have ability and political integrity, ability and quality simultaneously. Second, imparting knowledge and educating people is the root of responsibility for higher vocational colleges, the life of survival and the source of development. Teachers' behavior will affect students' quality. Thus, the duty of teachers is not only to impart knowledge, and the important task is to cultivate students' good moral character. The students' moral quality is the important sign of educating.

As the full-time training students in higher vocational college, besides having general features same as undergraduate students and college students, they also have some characteristics due to their own conditions, experience and growing environment, etc. Such as complex sources, poor and great different basic quality. Some students lack of selfless dedication and dedicated spirit, having the spirit of egoistic and narrow-minded. While the enterprises' requirements to the higher vocational graduates are loving their work and devoted to them, solidarity and cooperation, having good manners, selfless dedication and optimistic attitude. Thus there is some gap between the employers' needs and the higher vocational college students. As a teacher in higher vocational college, how to shorten the gap between the two has become our priority mission. So every teacher in higher vocational colleges should have the responsibility of imparting knowledge and educating people in the classrooms by aiming at students' characteristics and the enterprises' needs of enterprises.

\section{TEACHERS SHOULD CONSTANTLY IMPROVE THEIR OWN IDEOLOGICAL AND MORAL CULTIVATION}

Teachers are the main body in universities' construction of spiritual civilization and the angel of the whole societies' construction of spiritual civilization. It is teachers' vocation to impart knowledge and educate people. To give light to others, one should first have a bright light oneself; to light others, one should first have the fire oneself. So we must establish teachers' image reflecting the times' spirit, take correct world outlook, outlook on life and values as the spirit pillar of human soul's engineer. And there should form the common understanding and nurturing atmosphere of "I work too hard to cultivate a generation”

Generally speaking, the teacher is the engineer of the human soul. That is to say, teachers not only impart knowledge and skills, but also influence students' entire spiritual world, and this kind of influence has a special role. Because students' outlooks on world, life and other aspects are on the stage of the developing and maturing. Teachers and students are together from mornings to nights, and it is important to give full play to the teacher's teaching plays. It is difficult for us to imagine that a teacher who is no ideal, no ambition, no pursuit and no feelings and lack of professionalism and sense of responsibility is how to make a student to be a good student. We are more difficult to imagine that if a teacher is egoistic, assuming air of self-importance and lacking of love and dedication, even if the teacher makes students master more knowledge and skills, which still hasn't many positive effects on others and the whole society.

"Wind sneaked into the night, moisten things silently." Teachers' words and behavior influence students by environment effect, so teachers must teach by combining precept and example, adhere to the serious teaching attitude, rigorous academic spirit, and strict work style, strengthen occupational morality, individual cultural and life cultivation, use their good behavior to influence and infect students and strive to make themselves to be students' model.

\section{TEACHERS SHOULD HAVE EXCELLENT PROFESSIONAL QUALITIES}

Teachers' prestige in occupational college depends directly on their teaching levels. If teachers want to have a lofty prestige in students' minds, the first point is to have the profound knowledge and rigorous academic attitude and make every attempt to organize teaching. Only students 
admire you, they can respect and believe you, be close to you actively and come to you for advice, which then can play the effect of imparting knowledge and educating people. If teachers lack of certain professional knowledge and professional ability and have no way to tell why in front of the students, even have troubles in doing their jobs, then they will not go up to achieve the purpose of teaching and educating. Conversely, if they have high levels of teaching and strong ability, they will have a certain "qualification ", and students can easily convince them and be easily influenced. From the psychological perspective, this is the so-called "authority" or "the halo effect ". That is to say, in the same conditions, people are more likely to accept authority's influence, expand and generalize the advantages of authority in one aspect to others.

\section{TEACHERS SHOULD CARE, LOVE AND BE STRICT WITH STUDENTS}

Teachers should set up actively relationships with students through various forms, understand and grasp students' learning and thinking situation, be familiar with classes' characteristics and pay attention to the targets of teaching and education. No matter on classes or after classes, teachers should care, love and respect their students and help students to solve the problems about thought, learning and life. At the same time, teachers should be strict with students, especially carefully manage students' learning attitude, learning style, studying and testing discipline, timely detect problems and timely correct them.

To improve education is inseparable from teachers' systematic guidance and a special catalyst, which is love. Mr. Lu Xun once said: "Education is rooted in love ". Love is the source of education, and loving students is respecting students' personality, establishing the equality between teachers and students, sincerely communicating with the students and giving students sincere concern and help. They also should understand and trust students, be consistent but not too persistent, appreciate and care about their creative potential and discover everyone's shining points. Only being full of confidence and love to the educational objects, teachers will have the spirit of pursuing excellence and innovation. Our students are young and full of energy, so when criticizing and educating them, we must pay attention to the ways, methods and occasions and don't hurt their dignity. "To earn the heart by using heart, to earn the love by using love." Teachers' love is the raw power of successful education and the emotional foundation of educating students. Once the students feel this feeling, they will be close to their teachers, and then follow the way, so education will realize its fundamental function.

\section{TEACHERS SHOULD STRENGTHEN IDEOLOGICAL AND MORAL EDUCATION TO STUDENTS}

All the complete successes are the success of conducting oneself, all the complete failures are the failures of conducting oneself. Virtue without talent will cause delay, and talent without virtue will make things worse. Dante,
Italy poet, has a famous remark, a person can use moral to make up for his knowledge, but a person without enough moral is difficult to use knowledge to make up for his moral. In 1960s, Marshal Chen Yi told a thought-provoking words, the general meaning is, if a pilot in the air force has no way to fly an aircraft, which is not well; however, if he can fly an aircraft well, but fly the aircraft to the enemy, which would be much worse. Incompetent is not really good; without virtue is worse; having great ability without virtue is a disaster. Therefore, to strengthen the ideological and moral education of students is essential. We have reasons to believe that, only conducting moral and intellectual work at the same time, students can be forged to be the backbone of new times having both ability and political integrity. Strengthening the ideological and moral education of students, we can do from the following two aspects:

\section{A. To Make Full Use of TeachingMmaterials and Strengthen Students' Ideological Education.}

In order to teach and educate people on classes, teachers must consciously melt the ideological education to students and teaching materials into the teaching activities, so as to achieve the desired effect. Teachers should fully tap the educational factors of teaching materials and pay attention to cultivate students' creative thinking and innovation ability, learning ability, ability to withstand setbacks, ability to cooperate with others, spirit of competition and honesty and trustworthiness ...... which has important meaning to students' future adaptability to the knowledge and economy society.

\section{B. To MakeFull Use of the Actual Events Taking Place on Ourselves to Fosters Students' Ideological education.}

In January of this year, there happened snowstorm disaster in some provinces in southern China, from the national leadership to the masses of people, our wills unite like a fortress and we made comprehensive victory against the snowstorm disaster. "Wenchuan Earthquake" in this year made all Chinese people hold together, and lives' miracles appeared one by one under the ruins. A piece or a pile of touching screen is the best education material for students. In the classroom, we can make our students talk about their feelings and practices and cultivate their masters' spirit of being anxious to others' worrying and thinking of others' thoughts.

In short, the process of education is the process of souls' communication and impacting. A tree shakes another tree, a cloud pushes another cloud and a soul hits another soul. We teach and educate people, to be a model for others, have a long way to go.

\section{REFERENCES}

[1] Tian Jianguo, "New Ideas of Modern University,” Taishan Press, 2005

[2] Zhu Faren, "My Humble Opinion of Teaching and Educating People,” Occupational Education on Machinery, Nov. 2006

[3] Lin Jing, “On Teaching's Significance and Implementation,” Journal 
of Dalian Educational Institute, Sep. 2006

[4] Tao Yongjin, "Further Thinking on Teaching and Educating Work in Higher Vocational Colleges,” Journal of Changsha Tel \& Tec Vocational College, Jan. 2009

[5] Lin Zilan, "Simple Discussion on How to Improve Teaching and Educating Effect in Higher Vocational College,” Journal of Hubei Radio and TV University, Mar. 2010. 